\title{
A vision for a Reformed Christian college for South Africa
}

\begin{abstract}
Author:
Johannes D. Froneman ${ }^{1}$

Affiliation:

${ }^{1}$ School of Communication Studies, North-West

University, Potchefstroom,

South Africa

Correspondence to:

Johannes Froneman

Email:

jd.froneman@nwu.ac.za

Postal address:

Private Bag X6001,

Potchefstroom 2520,

South Africa

Dates:

Received: 30 June 2011

Accepted: 29 Sept. 2011

Published: 20 Nov. 2012

How to cite this article:

Foneman, J.D., 2012, A vision

for a Reformed Christian

college for South Africa,

Koers - Bulletin for Christian

Scholarship 77(1), Art. \#55,

4 pages. http://dx.doi.org/

10.4102/koers.v77i1.55

Note:

This article was developed

from a paper delivered at

the Koers-75 Conference on

'Worldview and Education',

held in Potchefstroom, South

Africa, from 30 May to 02

June 2011.
\end{abstract}

Hierdie artikel is ' $n$ verdere ontwikkeling van ' $n$

voordrag gelewer by die Koers-75 Konferensie oor

'Worldview and Education' in Potchefstroom, Suid-Afrika, vanaf 30 Mei tot 02 Junie 2011.

(C) 2012. The Authors.
A yawning gap has existed in the South African educational landscape since the effective termination of the Potchefstroom University (PU) for Christian Higher Education (CHE) by the government in 2004. The North-West University, which was formed through the merger of the PU for CHE and the University of North West, has been positioned as a value-driven university, but for all its good intentions and successes, it cannot (and never was intended to) continue the PU for CHE's tradition of Christian higher education. Given the growth of Christian schools in South Africa after 1994, it is clear that pupils from these and other schools have no Reformed option when they choose an institution of higher education. It is therefore suggested in this article that the concept of a new Christian college should find favour amongst Reformed Christians from all denominations, races, ethnic groups and languages in South Africa. The author argues that obstacles simply have to be overcome. A balanced Reformed approach which eschews extreme fundamentalism as well as attempts at undermining the fundamentals of the Christian faith is needed. Therefore, the formation of an inclusive pilot committee to investigate the idea is proposed.

'n Visie vir 'n reformatoriese Christelike kollege vir Suid-Afrika. Sedert die regering se terminering van die Potchefstroomse Universiteit (PU) vir Christelike Hoër Onderwys (CHO) in 2004, bestaan daar 'n groot gaping in Suid-Afrika se onderwyslandskap. Die Noordwes-Universiteit, wat uit die samesmelting van die PU vir $\mathrm{CHO}$ en die Universiteit van Noordwes ontstaan het, is op waardes gegrond, maar ondanks goeie bedoelings en suksesse kan dit nie die PU vir CHO se tradisie van hoër onderwys voortsit nie. Dit was ook nooit die bedoeling nie. Dit is duidelik dat diegene wat uit Christelike en ander skole kom nie meer ' $n$ Gereformeerde alternatief het om van te kies nie. Daarom word hier beklemtoon dat ' $n$ nuwe Christelike kollege byval sal vind onder Gereformeerde Christene uit alle kerkverbande, rasse, etiese groepe en tale in Suid-Afrika. Die outeur argumenteer dat hindernisse doodgewoon oorkom moet word. 'n Gebalanseerde Gereformeerde benadering wat sowel fundamentalisme as 'n afwatering van die basiese boustene van die Christelike geloof vermy, word voorgestel. In die lig hiervan word 'n inklusiewe loodskomitee voorgestel wat die saak verder kan ondersoek.

\section{Introduction}

Since the effective termination of the Potchefstroom University for Christian Higher Education by the government in 2004, there has been a yawning gap in the South African educational landscape. The North-West University (NWU), which was formed by merging the Potchefstroom University (PU) for Christian Higher Education (CHE) and the University of North West, has been positioned as a value-driven university, but for all its good intentions and successes, it cannot (and never was intended to) continue the PU for CHE's tradition of Christian higher education (see Froneman \& Swanepoel 2009).

Given the vibrancy of Christian schools in South Africa, particularly after 1994 when Christiannational education was finally scrapped and Christians of all persuasions had to seek new ways to educate their children if they found the secular government approach unacceptable (see Schoolguide 2011; ACSI 2011; BCVO 2011), the question is: what are the options of Christian pupils from Christian and state schools when they choose an institution of higher education?

Although St Augustine College (Catholic) and Helderberg College (Seventh Day Adventist) are Christian colleges, there is no college or university in South Africa where students from a Reformed Christian background can further their studies in an environment which will nurture them academically, intellectually and spiritually in a manner consistent with their Reformed background. 
I believe that piecemeal attempts to preserve small enclaves of Reformed Christian thinking at the NWU (or any other state university) will not suffice as it cannot be anything but a side-show which cannot embody and influence the institution as a whole. What we need is a new Christian college where the Reformed worldview has a central place, a college which, perhaps in a very modest way at first, will fill the gap left by the demise of the PU for CHE. And, may I add, one which is far more consistent in its attempts to integrate the Reformed world view at all levels, be it academic, administrative or social. A Christian institution of learning is, after all, never merely an academic institution. A new 'Calvin College' (or whatever name one prefers) will give those who support the idea of a college built on firm Reformed foundations the opportunity (or challenge) to start anew.

\section{A daunting task}

Whilst this is a daunting task, to say the least, it should not deter us. One can take heart from the many successful Christian colleges found all over the world. Those I visited, or have had some contact with, include Calvin College in Grand Rapids, United States of America (USA), New St Andrews College in Moscow, Idaho, USA, the Christelijke Hogeschool Ede in the Netherlands and the Redeemer University College in Canada. Through the years I have also had the pleasure of attending conferences where I met Reformed-minded Christian academics from across the globe. One can easily expand the list of Christian, in particular Reformed, colleges and universities.

The point I am making here is that there is a strong community of Christians all over the world who, I believe, would be only too happy to provide assistance. As a result of the speed and cost-effectiveness of the internet we no longer live in a far-away corner. Although technology presents its own problems, it can facilitate the sort of quality contact and access we will need.

Strong, direct links with like-minded institutions world-wide should therefore be fostered from the outset. This should not be a go-it-alone enterprise.

An important organisation in this respect is the Transnational Association of Christian Colleges and Schools (TRACS), which was established in 1971 'to promote the welfare, interests, and development of postsecondary institutions, whose mission is characterized by a distinctly Christian purpose', as defined in the association's Foundational Standards.

According to TRACS, it encourages each affiliated institution to develop its own distinctive character, whilst providing quality post-secondary education within the context of spiritual development. TRACS institutions place emphasis on high academic standards as well as Christian values (TRACS 2011). Obviously, any South African institution would have to comply with the laws of the country and the rules of the Council for Higher Education.

\section{Different types of Christian colleges}

As mentioned earlier, a few South African Christian colleges provide higher education where students can graduate in a number of areas. There are also institutions focused on theological or media training.

At this point we need to briefly state the obvious, namely that Christian colleges can differ markedly from one another, depending on their theological orientations. I am not in favour of a denominational college, as is often found in the USA and elsewhere in Africa. But the college should nevertheless be well-grounded and focused. Let us look at a few examples.

New St Andrews, viewed 24 May 2011, states the following on its website:

The ISI Guide to All-American Colleges describes New Saint Andrews College as 'intellectually rigorous and firmly grounded in the Christian tradition.' The College, which limits enrollment to no more than 200, also offers graduate programs in Trinitarian theology and classical Christian education. Students come from 20 different Christian denominations, 35 states and eight foreign countries.

The Christelijke Hogeschool Ede (2011), a more vocationally focused institution, states that the target profile of a $\mathrm{CHE}$ graduate includes the following elements:

- The student is able to account for his and her professional behaviour from a Christian view on the profession, relating to other convictions and viewpoints in a well-balanced and respectful manner.

- The student is motivated, has expertise and up-to-date knowledge of his and her field, is internationally oriented, and carries out his and her profession in a scrupulous and responsible manner.

- The student has developed a sense for the spiritual aspect of life. Not only does the student know 'what he must do to earn a living', he also is aware of 'who he is and what his purpose in life is'.

About Calvin College in Grand Rapids, Cornelius Plantinga Jr. (2011) declares:

Calvin is the distinctively Christian, academically excellent liberal arts college that shapes minds for intentional participation in the renewal of all things.

I believe we could summarize our calling in Christian college education as follows: in an academic setting, with the peculiar tools, perspectives, and resources of academe, we have to equip ourselves with the knowledge, the skills, and the attitudes that can be thrown into the struggle for shalom, the battle for universal wholeness and delight. The calling is exceedingly broad. We must never narrow it down to personal piety. But our role in the calling at this place is particularly academic: we must not confuse it with the role of other Christian agencies. So what we need is an extraordinarily broad concept of the general Christian project in the world combined with a sufficiently restricted and academic concept of our present role in preparing to take our place in this project. (n.p.)

And so one can continue. We have a rich heritage of Christian thought to underpin any new Christian college. If we choose 
carefully whom to use as examples and mentors, we can place the proposed college on a sound footing from the outset. Obviously, one will not be able (or inclined) to replicate any one particular institution. Our needs and context are too different, as are laws, policies and demographic realities. But there are many wonderful role models which can inform us. They are institutions that strive in different ways, some very successfully, to be true to their vision and mission whilst at the same time interpreting them in contemporary, sometimes very creative ways. They differ from secular institutions because they strive (often very successfully) to integrate their Reformed worldview with all the dimensions of an institution of learning. These institutions are therefore much more than colleges or universities with an added-on (Christian) name, as is unfortunately often found.

\section{An online initiative}

The Institute for Christian Higher Education, a South African initiative, is in the process of registering a company and has signed an agreement with the Dutch Open University, which will provide free access to study material (Van Eems 2011). According to Bouwe van Eems, who is involved with this initiative, the idea is to provide online courses from 2012. How the Reformed vision will be integrated into these courses is unclear, but Van Eems is keen to discuss this with like-minded Christians. What is important is their acceptance of an online model. This is understandable, but not without problems. As Roy Attwood (2011), president of the New St Andrews College writes:

According to a recent Inside Higher Ed article, a number of Christian colleges and universities are booming online... Such growth is not necessarily something to be pleased about. The growth of online classes and enrollment at Christian institutions indicates that Christians are choosing a form of education that stresses the downloading of information. What is missing from online education is the formative character of authentic Christian education (Eph. 6:4, Luke 6:40). (n.p.)

Attwood (2011) adds that online programmes:

may add convenience and reduce costs for information acquisition, but they remain severely limited in their ability to give the personal mentoring Christian students need to grow spiritually and to mature in their Christian character and identity as biblically expected. (n.p.)

Until online education makes learning as personal as the face-to-face classroom of out of classroom experience, online programmes won't be something that Christians should flock to. The alternative to bad and expensive Christian colleges is not an inexpensive and impersonal information download. Jesus expects more from our teachers than that.

So whilst any genuine attempt at providing higher education within a Reformed framework has to be applauded, Attwood's warning in this regard must be taken seriously.

\section{Various Christian schools}

Another real challenge is to accommodate students from different backgrounds. I mentioned the growth in Christian schools. This includes the Afrikaans Christelike Volkseie Onderwys movement. These schools place a high premium not only on their Christian faith, but also on Afrikaner identity. Students from this background may have to rub shoulders with home-schooled students. In some instances the latter will come from a very similar ideological background, but in other instances not. There are also many evangelically inclined parents who home-school their children. Add to this the Accelerated Christian Education (ACE) schools which are often accommodated in a charismatic or evangelical environment. And then many Christian students come from state schools who maintain a strong Christian ethos notwithstanding attempts at enforcing secularism.

The student body at a Reformed Christian college will therefore be less monolithic than one would imagine at first, and this presents its own challenges.

\section{Conclusion}

The concept of a new Christian college should find favour amongst Reformed Christians from all denominations, races, ethnic groups and languages in South Africa. But given the diversity of even the Reformed strand of Christianity, it needs to be accepted that it is impossible to please everyone. Christians, especially Reformed Christians, can be notoriously hard-headed. But the need for Christian higher education is now more acute than ever. The obstacles simply have to be overcome. A balanced Reformed approach which eschews extreme fundamentalism as well as attempts at undermining the fundamentals of the Christian faith, is needed.

Is this the dream of one or a few? Can we garner the support of a critical mass? Can we overcome differences and do something really meaningful which will have an impact on 21st century South Africa? Or will we continue to live in the past and bemoan what might have been, what we had had and had lost? I cannot accept this. It's time to consider building a new Calvin College.

Therefore, I suggest the formation of an inclusive pilot committee to investigate the idea. The Koers Association and the Association of Christian Higher Education (VCHO) may well provide the institutional backing needed to get the ball rolling. When Koers celebrates its centenary, it may happen at South Africa's own Calvin College. This will not depend on our ability to create a new institution, but on our faithfulness and on the grace of God. Are we ready to take up the challenge?

\section{Acknowledgements Competing interest}

The author is a professor at the North-West University (NWU). He has previously voiced a critical opinion about the government-enforced merger of the former Potchefstroom University for Christian Higher Education (PU for CHE) with the University of North-West to form the NWU. The views expressed in this article should not be regarded as 
criticism of the present NWU, but is solely intended as an independent view regarding the future of non-state-funded higher Christian education in South Africa.

\section{References}

The Association of Christian Schools International (ACSI), 2011, Welcome to the ACSI website, viewed 06 September 2011, from http://acsi.co.za

Attwood, R.A., 2011, 'Growth of online education among Christians highlights problem, not solution' in New Saint Andrews College, viewed 24 May 2011, from http://www.nsa.edu/onhighered/?p=487

Beweging vir Christelik-Volkseie Onderwys (BCVO), 2011, Meer inligting oor die BCVO viewed 06 September 2011, from http://www.bcvo.co.za/pages/wie-is-ons.html
Christelijke Hogeschool Ede, 2011, Internal Visitors, viewed 24 May 2011, from http:// topshare.che.nl/english/229397/229403

Froneman, J.D. \& Swanepoel, T., 2009, 'Teaching journalism prior to and after the demise of Christian higher education at Potchefstroom', Koers - Bulletin for Christian Scholarship 74 (1 \& 2), 265-284.

New Saint Andrews, 2011, About NSA, viewed 24 May 2011, from http://www.nsa. edu/aboutnsa/aboutnsa.php

Plantiga, C., 2011, 'Educating for Shalom: Our Calling as a Christian College', in Calvin minds in the making, viewed 07 September 2011, from http://www.calvin.edu/ about/shalom.html

Schoolguide, 2011, Looking for schools in South Africa?, viewed 06 September 2011, from http://www.schoolguide.co.za

Transnational Association of Christian Colleges and Schools (TRACS), 2011, Downloads, viewed 06 April 2011 from http://www.tracs.org/downloads.htm

Van Eems, B., 2011, email, 12 April 2011. 